医道白寿8-2-3

23日 (土) 第2会場

\title{
VUR と小児神経因性膀胱
}

\section{星ヶ丘厚生年金病院泌尿器科 \\ 百瀬 均}

小児神経因性膀胱の代表的疾患である二分脊椎患者において、VUR は腎機能障害の重大な危険因子であり、その病因としては先天的な膀脱 三角部や康管口の未熟性だけでなく、膀胱内の高圧状態が大きく関与していると考えられる。VUR を合併する二分春椎患者に対しては、まず 間欠導尿による低圧排尿の獲得が試みられ、さらに排尿筋過活動や低コンプライアンス膀胱などの高圧蓄尿状態を呈する場合には抗コリン薬 が併用されるが、これらの保存的な治療で効果が得られない場合は手術療法の適応となる。二分脊椎患者のVURに対する手術法は、侵襲性の 低い順に内視鏡的注入療法、尿管膀胱新吻合術、腸管利用膀胱拡大術の併用に分かれるが、演者らの施設での成績は以下の通りである。内視 鏡的注入療法について演者らは 14 例 22 尿管に対して GAX コラーゲンを注入し良好な短期成績を得たが、 3 年以上経過観察された 32 尿管を 対象とした長期成績結果では、G1 : 83.3\%、G2:37.5\%、G3:28.6\%、G4 以上 $0 \%$ であり、GAX コラーゲンを用いた内視鏡的注入療法は G1 以外の症例については長期的には無効であると結論付けられた。一方、Cohen 法を用いた尿管膀胱新吻合術について演者らは、術後6 13 年間 (平均 8.9 年) 経過を追跡できた 22 例 38 尿管について検討し、VUR 非再発率 $90.5 \%$ という良好な成績を報告している。しかし一方で術 前の膀胱コンプライアンスが $10 \mathrm{ml} / \mathrm{cmH}_{2} \mathrm{O}$ 以下であった 5 例中 4 例において、その後の萎縮膀胱の增悪に対して腸管利用膀脱拡大術が施行さ れており、低コンプライアンス膀腃にVURを生じた症例について尿管膀胱新吻合術のみを行なうことの問題点を指摘した。現在、演者らは低 コンプライアンス膀胱を合併したVUR 症例に対する根治潦法として、尿管新吻合術を併用した回腸利用膀胱拡大術を第一選択としている。尿 管新吻合については、膀胱内操作が可能な症例ではCohen 法を用い、膀胱壁肥厚や肉柱形成の著しい症例ではLeDuc-Camey 法を用いて尿管 と回腸膀腃を吻合している。回腸利用膀胱拡大術は手術侵襲が大きい点、電解質異常などの長期合併症を来たす可能性を有する点、また健常 組織である腸管にメ久を加える点に問題点を残すが、VURに対する効果と膀脱の低圧環境の碓保の点で信頼性の高い治療法である。以上の各 治療法の特性を勘案した結果、演者らは low gradeの VURに対しては内視鏡的注入療法、 high grade の VUR 症例のうち膀胱コンプライアン スの良好なものについてはCohen 法、低コンプライアンス膀胱症例については回腸利用膀胱拡大術併用、をそれぞれ手術療法の第一選択とし ている。現在、わが国では GAX コラーゲンが使用できない状況であるが、より高い効果が報告されている非動物由来安定化ヒアルロン酸ナト リウム/デキストラノマー・ゲルが臨床使用可能となれば、上記の選択基準がより低侵襲な形にかわるものと期待される。

\section{医道白寿8-2-4}

23日 (土) 第2会場

\section{小児消化器外科疾患（直腸肛門奇形含む）と腎泌尿器疾患の掛け橋としての医療を目指して}

\author{
順天堂大学小児外科 \\ 山高 篤行
}

小児消化器外科疾患（直腸肛門奇形含む）には少なからず腎泌尿器疾患を合併する。当科の経験では、直腸肛門奇形 ( $\mathrm{n}=371)$ の 26.6\% に腎泌尿器疾患を伴い、中でもVURの合併頻度は高い。直腸肛門奇形の極型である Cloacal anomaly $(\mathrm{n}=25)$ に至っては、その半数にVUR を認めている。VURに小児消化器外科疾患を伴った場合、VURの治療は、年齢、VURの Grade、UTI の有無、合併する消化管疾患によっ て異なるため、患児 1 人 1 人に適したオーダーメイド治療が必要となる。当科における経験例を供覧し、小児消化器外科疾患を伴う VUR の治療について述べさせて頂きたいと考えている。

症例 1）右 Grade V VUR（腎瘏痕あり）に、先天性食道閉鎖、Cloacal anomaly を合併した女监。食道閉鎖根治術および人工肛門造設術 （日齢０日）施行後、反復性UTIのため、乳児期（生後７ヶ月）に右Cohen 法を行った。左腎には膀胱造影上VURを認めなかったものの 腎㓔痕を認めていた。生後 15 ヶ月時に、Posterior sagittal anorecto-vaginoplasty を施行、膀胱容量が正常であったため Bladder augmentation は要しなかった。その後、4 歳時に膵炎を発症、精査にて先天性胆道拡張症を認め根治術を施行した。

症例 2) 右 Grade I VUR（無機能腎）に高位鎖肛（直腸尿道㾇）を合併した男児。左腎機能は正常。人工肛門造設後、生後 5 ヶ月時に腹 腔鏡下直腸尿道瘦切離直腸 pull-through を施行。術後経過は良好であったが、10歳時より右腰背部痛と発熱を繰り返すようになり近医を 受診し、右 VUR を指摘された。当科にて 11 歳時、右無機能腎に対し後腹膜鏡下右腎尿管摘出術を施行した。

症例 3) 右 Grade V VUR (低形成腎)、左無機能腎に Hirschsprung 氏病 (以下 H 病)を合併した男児。出生直後からの腹部膨満の精査に より $\mathrm{H}$ 病と診断された。その際、右低形成腎、左無機能腎の合併を指摘された。治療方針は、H病が洗腸管理にてコントロールされていた ため、腎機能を経過観察しながら体重増加を待ち、1 期的 $\mathrm{H}$ 病根治術 (腹腔鏡補助下結腸 pull-through) を行うこととした。しかし、生後 15 ケ月時にUTI を発症し、膀胱造影にて右 VURの存在が判明した。内科的治療でUTIがコントロールされていたため、3歳時にCohen 法による逆流防止術を施行した。H 病に関しては、当初の治療方針を変更し、まず人工肛門造設を行い、その後根治術を行うこととした。 近年、洗腸で排便コントロールが可能な $\mathrm{H}$ 病に対しては、人工肛門を造設せず 1 期的根治術が行われているが、患児の場合は、低機能腎の ためアミノグリコシド系抗生剤の使用を避けたく、術後感染の risk を可及的に回避するため人工肛門の造設が必要であると判断した。 